\title{
Congenital lipoid adrenal hyperplasia due to STAR deficency
}

INSERM

\section{Source}

INSERM. (1999). Orphanet: an online rare disease and orphan drug data base. Congenital lipoid adrenal hyperplasia due to STAR deficency. ORPHA:90790

Cong enital lipoid adrenal hyperplasia (CLAH) is one of the most severe forms of congenital adrenal hyperplasia ( $\mathrm{CAH}$; see this term) characterized by severe adrenal insufficiency and sex reversal in males. 